\title{
The Impact of Applying AAOIFI in Islamic Banks. Case Study in Iraqi Islamic Banks - Part I -
}

\author{
Dhiaa Al Deen ALAZZAWI, PhD, Professor Ileana NIȘULESCU-ASHRAFZADEH, PhD
}

Bucharest University of Economic Studies, Romania

\begin{abstract}
The objective of this research is to study the impact of applying the AAOIFIs in Islamic banks, while referring to the impact of applying the AAOIFIs in Arab countries, the focus being on the Iraqi Islamic banks. The major responsibility of the AAOIFIs is to guarantee that accounting methods comply with Sharia - Islamic law, which is only used by a few financial institutions in Islamic countries especially Islamic banks. The AAOIFIs are an enchanting prospect coming from the holy scripts.

The researchers obtained the data for the study through a questionnaire prepared for this purpose, distributed to 68 workers in the field of Islamic banks. The researchers received 52 responses from several Islamic banks. The study concluded with the set of results that Islamic banks are seeking for the profitability without increasing the security for their deposits or attracting more investors, and the customers of Islamic banks are seeking for "legal benefits" by their investment.

The study led to the conclusion that the adoption of the AAOIFIs in Islamic banks will not help attracting foreign investments. The study suggested there is an urgent and actual need to adopt and implement the IFRSs instead of the AAOIFIs within the sample of the study and include other institutions with a similar environment like Islamic banks.
\end{abstract}

Key terms: AAOIFI, Shariah, Murabaha, Iraqi Islamic banks

JEL Classification: M40, G21

To cite this article: Dhiaa AI Deen Alazzawi, lleana Nișulescu-Ashrafzadeh, The Impact of Applying AAOIFI in Islamic Banks. Case Study in Iraqi Islamic Banks (I), CECCAR Business Review, N 9/2021, pp. 45-51, DOI: http://dx.doi.org/10.37945/ cbr.2021.09.05

\section{Introduction}

The importance of this research for the banking sector in the light of the recent years, especially in Iraq, is all the greater as the banking system suffers from weak banking and low liquidity, deposits, income and profitability in some banks, Islamic banks in particular, have seen their stock prices fall in recent years due to the economic and financial crisis and the economic downturn Iraq has suffered from, for known reasons. The most important reason that motivated the researchers on the choice of this topic is that the Islamic banks work to support the economy's growth and attract more investors.

They are many purposes that made the researchers to choose this study and some of the most the important are:

1. Pushing Iraqi Islamic banks to switch from applying the AAOIFIs, issued by AAOIFI (Accounting and Auditing Organization for Islamic Financial Institutions), to applying the IFRSs, issued by IASB (International Accounting Standards Board), because it contributes to improving the results of their activities and financial outcome. 
2. The application of Murabaha will increase the annual rate of return on deposits and the number of depositors and investors in Iraqi Islamic banks.

The aim of the study, which relied on the questionnaire, was highlighting a couple of objectives such as the following:

1. Explain the impact of the AAOIFIs application in general and Murabaha standard in particular, on the activities and financial outcome of Iraqi Islamic banks.

2. Highlighting the problems facing Iraqi Islamic banks for small number of depositors.

The researchers found the following hypotheses to be tested: while applying AAOIFIs in general and Murabaha in particular, the annual rate is increasing, as well as the number of depositors and investors in Islamic banks.

This research will take a general view of the AAOIFIs, their advantages and disadvantages, which has received increased attention over the entire world; it's led to the result of the growing interest in Islamic accounting procedures. The AAOIFI Standards are limited to Islamic countries or a few Islamic financial institutions.

The AAOIFIs plays a role especially in regulating two concepts unique to Islam - Riba usury and Zakat "compulsory charity special donations for the poor".

The researchers had chosen Iraq environment to study and examine the impact of applying the AAOIFIs considering that Iraq is one of the Muslim countries that has many Islamic banks.

An Islamic bank is a financial institution which is based on executing partnership contracts which involve a commitment to practice Sharia-permitted Banking business on a non-interest basis, neither paying nor receiving interest, and according to the banking transaction patterns that does not conflict with the provisions of Islamic Sharia, whether in the area of accepting deposits or providing any banking or financial investment services. Islamic banks have been operating for over nearly 30 years in the Gulf and the Muslim countries and that they have been successful in developing banking business according to the Islamic law provisions, and they also had a serious contribution to investment projects, financing and economic development.

\section{The research methodology}

In order to achieve the proposed objectives of this study, we conducted a study in the Islamic banks by using a questionnaire which consists of 13 questions that answer the hypotheses of the research. The questionnaire was distributed to 10 Islamic banks. The research problem is that the number of depositors and investors in Iraqi Islamic banks is not increasing while applying Murabaha.

\section{Earlier studies}

AAOIFI governance disclosure in Islamic banks that mandatorily adopt AAOIFI Standards. The aims of this thesis are as follows: first, to measure the level of AAOIFI governance disclosure; second, to identify the determinants of AAOIFI governance disclosure (Elgattani, 2018).

The goal of AAOIFI is to develop modern accounting philosophy that tests these aims against Islamic Shariah, accepting those that are Shariah-compliant and disallowing those that are Shariah-incompatible (Maurer, 2010).

The Shariah' Committee is a board which is independent in directing, reviewing and supervising an Islamic financial institution (IFI). It consists of those who are specialised in Fiqh Muāmalāt or those who know it with expertise in other fields.

The result of the research of Nguyen (2021) suggest that the effectiveness of audit and Sharia committees reduces bank risk primarily through the following mechanisms: traditional bank audit committees drive bank risk down through incentives to maintain greater capital ratios as well as the profit reallocation effect, whereas Sharia committees drive bank risk down through incentives to enhance efficiency and decrease profit volatility in Islamic banks. 
Al-Duhaidahawi et al. (2019) investigated whether the financial Inclusion play a significant role in achieving the competitive advantage in Iraqi banks particularly, Islamic banks. By using questionnaires, the results of his study were the significant effect of financial comprehensiveness on achieving the objectives of institutions regarding customers.

\section{The concept of AAOIFI}

The expansion of Islamic financial markets and institutions, culminating with the increased interest in Islamic banking, insurance, and capital markets, raises the need for different accounting requirements. Islamic accounting needs to serve different principles of financial practice that are founding the Islamic countries and Sharia requirements. This led to the need of creating the AAOIFIs (Rahman and Rahim, 2007). "Sharia is what God has decreed for His servants on earth, and the purpose of the servant and duties assigned to him from prayer, fasting, Zakat and Hajj."

AAOIFI, a non-profit organization established in Bahrain, is currently the leading organization focused on developing standards to balance various financial activities in the Islamic world, most notably accounting, auditing, governance, and Sharia. With 88 standards and more on the way, AAOIFI is supported by over 220 members from 45 countries. These members include financial institutions as well as law firms, ushering in an unprecedented era of growing unity. In history records from 1494, according to Kam (1990), the previous accounting principals were from Piccioli's book created in Venice, Italy.

According to Muhammad in 2002, at his book Pengantar Akuntansi Syariah, Muslim merchants had known accounting principles since before the $9^{\text {th }}$ century, which is before Piccioli even began writing his book. However, the history of Islamic accounting can be traced back to the requirement for different accounting standards. The growing number of Islamic financial institutions and market places, as well as the desire to create financial tools that fit the Sharia's standards to satisfying potential shareholders.

According to the basis of Islamic believe, Muslims are obligated by God to keep track of their transactions, "O ye who believe! When ye deal with each other, in transactions involving future obligations in a fixed period of time, reduce them to writing; let a scribe write down faithfully as between the parties." (Al Qur'an). A growing number of IFIs mixed with the growing realization of conventional Islamic corporation accounting inequalities, which led to the gathering of IFIs in Algiers on the $26^{\text {th }}$ of February, 1990, to establish-according to the Articles of Association of AAOIFI - a new body, was designed to fulfil the Qur'an's requirements. Through a series of conferences, seminars, and the development of IASs, it was expected that AAOIFI would lead out in creating a viable groundwork in which to discuss Islamic accounting practices. After that the AAOIFIs were registered (11 Ramadan 1411H). "According to the Muslim calendar AH" this corresponds to 27 March, 1991 in the State of Bahrain as an international non-profit organization.

\section{The advantages and the disadvantages of the AAOIFIs}

The researchers conclude that they are many advantages such the ones listed below:

1. Provides common standards for the Islamic financial industry and banks.

2. Helps to shape market outlines and define the industry's distinctive features.

3. Provides the privacy of Islamic banking and financial operations in terms of the intellectual and practical basis that distinguishes them from conventional practices.

4. Islamic standards provide the necessary tools for the Islamic transaction's requirements, and help procuring an honest and fair presentation of the financial position of the Islamic financial institutions.

5. Obligations for trust are provided to the users of financial statements, in the transactions of Islamic financial institutions, and the foundations of homogeneity are based on financial reports issued by those institutions, which increases the element of clarity and transparency in the interpretation and analysis the financial statements. 
6. The Islamic standards are based on the special features that distinguish Islamic banks and financial operations.

7. It takes into consideration when developing Islamic standards reverting to the IFRS.

8. The inevitability of the global acceptance of applying the IFRSs across the world, but applying the IFRSs in Islamic banks is a disadvantage because the international standards are focused on the interest, which is not allowed in Islamic law Sharia, as well as in Islamic institution.

However, Rahman and Rahim (2007) said that Islamic financial institutions could not comply with the IFRSs in their financial reporting because Islamic financial institutions have different and special requirements. Moreover, the secretary general of the AAOIFI Islamic standards, Mohamad Nedal, said that the standards have helped Islamic financial institutions all the time and throughout the world in Muslim countries and some IFIs operating in European jurisdiction to assure that the produces and services they offered are in compliance with Islamic law Sharia.

On the other hand, there are many disadvantages of AAOIFI such as those listed below:

1. In fact, the US and the European Union do not adopt the AAOIFIs, in comparison with other Muslim countries such as Saudi Arabia, UAE, Qatar, Malaysia, and others. That means the IFIs or the companies which are established in the European countries, the USA or other jurisdictions that apply the IFRSs are required to change between two reporting systems internal (AAOIFI) to external (IFRS or GAAP) to make it fit.

2. Applying the AAOIFIs incurs high costs. It doesn't matter if the company has a large business or a small one. Both would need to use the same principles and structures required by the AAOIFIs. In the case of small businesses, it would cost more than for the large ones, the reason being that both will incur the same expenses such as qualifying and training staff as well as hire accountants.

3. It's hard to make the comparison of financial statements across markets by using the AAOIFIs, since the IFRSs have been the standards of financial reporting globally.

4. There is a small number of companies across the entire world that apply the AAOIFIs. The IFRSs already have a huge user base, which helps the companies to get into the financial markets by having the financial statements already prepared in the same language by applying the IFRSs.

5. AAOIFI doesn't have the flexibility to use some different methods derived by the management's desire to alter the financial statement reports.

\section{The structure of AAOIFI}

The AAOIFIs have been restructured since 1995, bringing it closer to the Anglo-Saxon standards. The organizational structure of the AAOIFIs was given order by "a body of recorded laws and conventions that were in effect throughout the Anglo-Saxon period in England". The AAOIFI organization consists of the "General Institution, Council of Trustees, Accounting \& Auditing Standards Board, General Secretariat, and Shariah Board". (AAOIFI, 2008)

All founding, observing, and supporting members make up the General Institution. As far as the members are concerned, they are responsible for regulatory and supervisory functions. The Council of Trustees is composed of regulators, accountants, and other financial statement users. The accounting \& auditing standards was arranged the guidelines for international financial institutions. The General Secretariat serves as the organization's administrative director. He is in charge of the superscript and oversees the AAOIFI's daily operations, as well as representing the organization at conferences and events. Finally, Scholars with expertise in Fiqh are represented on the Shariah Board, academics representing SSBs (Sharia Supervisory Boards) in Islamic financial institutions say that Figh is a human s ability to understand Sharia.". They're in charge of double-checking the AAOIFI Standards for Islamic conformity. Furthermore, they are responsible for approving concepts and applications among Sharia Supervisory Boards of Islamic financial institutions in order to avoid any dispute and rebellion in their activities. (AAOIFI, 2008) 


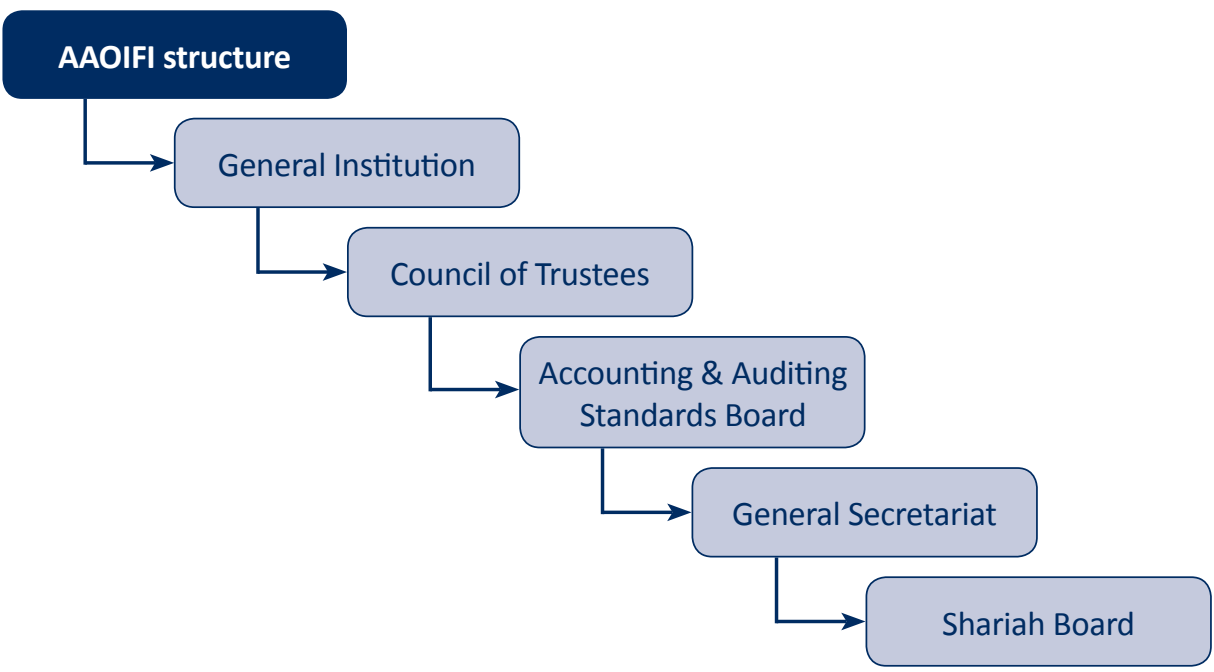

Figure 1. AAOIFI structure

Source: Contribution of researchers.

\section{The AAOIFI Standards}

One of AAOIFI s tasks covers the creation and publication of standards that are approved by a wide community of over 200 members from 40 different countries. These members may be law firms, auditing firms, or accounting firms, or even Islamic banks, but they abide by the well-developed and published standards. The standards have also managed to achieve a high level of Islamic finance practice agreement throughout the major Islamic financial markets, resulting in increased Islamic institution fulfilment. Accounting and auditing governance, ethics, and Sharia norms are also issued by AAOIFI. AAOIFI has released a total of 88 standards up to date.

The AAOIFIs are particularly beneficial to Islamic financial institutions and other industries. Furthermore, the standards are based on the practices of Islamic financial institutions (AAOIFI, 2008).



Figure 2. The classification for AAOIFI Standards

Source: Contribution of researchers.

The researchers found that the AAOIFI Standards above are still under improvement and it may be incised in the near future regarding to the needs of Islamic law Sharia.

\section{The application of the AAOIFI Standards}

Because Muslim countries must adhere to international standards, some of them have their own set of rules and Islamic laws. For example, some Islamic banks implement all of the IFRS standards, with the exception of specific interest rate limits Muslims are prohibited from receiving any form of interest since it is termed Riba, or usury. In Islamic banking, Riba, or charged interest, is prohibited since it is considered exploitative to the borrower. Riba may relate to any form of usury, according on how Sharia is interpreted, while some believe it only applies to instances in which exorbitant interest is requested. Many regions of the Islamic world, particularly 
Islamic banks and zakah institutions, are adopting the AAOIFI Standards as an obligatory rule. As a result of the use of these concepts, bank investors can now profit from their investments.

Most of the topics covered and the extent of accounting standards will be intersected by AAOIFI Standards. Although the majority of Islamic academics favoured the use of a more constructive approach, AAOIFI was scarcely condemned for not being competent in implementing accounting techniques. (Ibrahim et al., 2003) Despite the fact that AAOIFI criteria are acknowledged by Islamic financial institutions, some organizations, such as Islamic banks and zakah institutions, it appears it is limited to be adopted it. The jurisdictions in which AAOIFI Standards are mandatory are: Bahrain, Dubai International Financial Centre, Jordan, Qatar Financial Centre, Sudan, South Africa for investment management, Syria, and Islamic Development Bank Group. These standards have been adopted in a variety of other countries and IFI. The countries that adopted the AAOIFIs are Saudi Aribia, Malaysia, Lebanon, Indonesia, Brunei, Kuwait, Pakistan, United Arab Emirates, Jourdan.

\section{Puslim countries and investors}

Islamic finance, a unique form of investment that corresponds to the ideas of socially responsible investing, is rising in popularity on financial markets. Islamic finance is a fair way of financing based on Sharia law. The most distinctive element of Islamic finance is the prohibition of interest, whether nominal or excessive, compound or simple, fixed or not fixed. To comply with Sharia, an investment must not require interest also known as Riba.

IFIs operate under the idea of forbidding immoral transactions and encouraging greater social fairness through risk and reward. On mutually agreed parameters, the customer and the Islamic bank share the risk of any investment and split any profits. Islamic finance prohibits profiteering by exploiting and passing financial risks to one of the contracting parties. Rather, it aims to safeguard society from deception, fraud, and social tensions. Accountability is also emphasized in Sharia-compliant products, fairness and transparency. (Usmani, 2010)

In addition to risk-sharing and the ban of interest, Sharia prohibits investing in firms that deal with alcohol, pork, gambling, firearms, cigarettes, media, traditional financial institutions, pornography, and anything else it deems inappropriate (unlawful).

Sharia boards have specified for all Islamic investment fund companies, which not only provide approvals on individual investments on a regular basis, but also conduct Sharia audit annually to ensure all activities of the investment funds are fully compliant, when Sharia-compliant investments receive company dividends generated as part of a company's normal business operations.

Purification process takes place when a large diversified corporation may be Sharia-compliant but may own a small financial subsidiary deemed non-compliant so any portion of income received from non-Sharia-compliant activities are paid to charity and thereby "purified".

The most common forms of Sharia-compliant investment funds are equity funds, real estate funds and money market funds. These investment funds employ Islamic contracts which ensure that the terms and rights of all parties are safeguarded in conformity with Islamic principles examples and definitions given below:

$\checkmark$ Musharakah: A partnership where profits are shared according to a pre-agreed ratio while losses are shared in proportion to the capital investment of each partner. This equity financing arrangement is widely regarded as the purest form of Islamic business.

$\checkmark$ Mudarabah: A partnership between an investor who provides the capital and an agent when puts on effort and manages the business. In this agreement profits are shared on a pre-agreed ratio, while losses are only incurred by the investor.

$\checkmark$ ljarah: An Islamic lease agreement instead of lending money and earning interest, ljarah allows the investor to earn profits by charging rentals on the asset leased to the user.

$\checkmark$ Murabaha: Purchase and sale of an asset at a mark-up price. Instead of lending money, the investor purchases the desired asset from a third party and sells it at a predetermined mark-up price to the user. By paying this higher price over instalments, the user of the asset has effectively obtained credit without paying interest. 
The classical equity instruments in Islamic conventional law (Musharakah and Mudarabah) require partnership, and risk and profit sharing. In financial markets, investing in stocks and equity funds is permitted but it must follow certain guidelines (Farooq, 2007).

Conventional interest-based lending or bonds are ruled out in Islamic finance because they rely on interest. Instead, asset-backed financing is encouraged with the risk being shared by the provider and the user of the asset.

To be continued...

\section{References}

1. Ahmed, H. (2014), Islamic Banking and Shari'ah Compliance: A Product Development Perspective, Journal of Islamic Finance, Vol. 3, No. 2, pp. 15-29.

2. Al-Askar, S.R. (2005), Client and Employee Perceptions of Islamic Banking in Saudi Arabia, Durham Theses, Durham University.

3. Al-Duhaidahawi, H.M.K., Zhang, J., Abdulreza, M.S., Harjan, S.A., Shah, S.S.H. (2019), The Role of Financial Inclusion and Competitive Advantage: Evidence from Iraqi Islamic Banks, International Journal of Economics and Financial Issues, Vol. 9, No. 3, pp. 193-199.

4. Ben Arab, M., Elmelki, A. (2008), Managing Risks and Liquidity in an Interest Free Banking Framework: The Case of the Islamic Banks, International Journal of Business and Management, Vol. 3, No. 9, pp. 80-95.

5. Cornett, M.M., Guo, L., Khaksari, S., Tehranian, H. (2010), The Impact of State Ownership on Performance Differences in Privately-Owned Versus State-Owned Banks: An International Comparison, Journal of Financial Intermediation, Vol. 19, No. 1, pp. 74-94.

6. Elgattani, T. (2018), AAOIFI Governance Disclosure in Islamic Banks: Its Determinants and Impact on Performance, Doctoral Thesis, University of Portsmouth.

7. Farooq, M.O. (2007), Partnership, Equity-Financing and Islamic Finance: Whither Profit-Loss Sharing, Review of Islamic Economics, Vol. 11, Special Issue, pp. 67-88.

8. Ibrahim, A.M., Yahya, S.B., Abdalla, Y.A. (2003), Examining the Influence of the Characteristics of Islamic Banks and Shariah Supervisory Board on the Level of Social Responsibility Disclosure: A Review from Sudan, International Journal of Business and Innovation, Vol. 2, No. 3, pp. 23-51.

9. Iqbal, Z., Mirakhor, A. (2011), The Islamic Financial System, in An Introduction to Islamic Finance: Theory and Practice, Second Edition, pp. 113-136.

10. Kam, V. (1990), Review of Arithmetic, Geometry, and Proportions.

11. Maurer, B. (2010), Form Versus Substance: AAOIFI Projects and Islamic Fundamentals in the Case of Sukuk, Journal of Islamic Accounting and Business Research, Vol. 1, No. 1, pp. 32-41.

12. Muhammad (2002), Pengantar Akuntansi Syariah, Salemba Empat, Jakarta.

13. Nguyen, Q.K. (2021), Oversight of Bank Risk-Taking by Audit Committees and Sharia Committees: Conventional vs Islamic Banks, Heliyon, Vol. 7, No. 8.

14. Rahman, A., Rahim, A. (2007), Islamic Microfinance: A Missing Component in Islamic Banking (Islamic Economics: Theoretical and Practical Perspectives in a Global Context), Kyoto Bulletin of Islamic Area Studies, Vol. 1, No. 2, pp. 38-53.

15. Rahman, A., Rahim, A. (2007), Pre-Requisites for Effective Integration of Zakat into Mainstream Islamic Financial System in Malaysia, Islamic Economic Studies, Vol. 14, No. 1-2, pp. 91-107.

16. Usmani, M.T. (2010), Present Financial Crisis. Causes and Remedies from Islamic Perspective.

17. AAOIFI (2002), https://.aaoifi.com.

18. AAOIFI (2008), https://.aaoifi.com.

19. Al Qur'an Chapter 2: Sūrat Al-Baqarah (The Cow), https://corpus.quran.com.

20. Central Bank of Iraq (2020), The Edition, https://www.cbi.iq. 